PLEASE NOTE! THIS IS SELF-ARCHIVED VERSION OF THE ORIGINAL ARTICLE

To cite this Article: A. Guilland (2018) CONSIDERATIONS FOR SOLVING THE SKILLS MISMATCH OF YOUNG GRADUATES AND REQUIREMENTS OF BUSINESS WORLD, INTED2018 Proceedings, pp. 2252-2259.

doi: $10.21125 /$ inted.2018.0423

URL: https://library.iated.org/view/GUILLAND2018CON 


\title{
CONSIDERATIONS FOR SOLVING THE SKILLS MISMATCH OF YOUNG GRADUATES AND REQUIREMENTS OF BUSINESS WORLD
}

\author{
A. Guilland \\ Laurea University of Applied Sciences (FINLAND)
}

\begin{abstract}
More and more young people are unemployed. Young European graduates face severe difficulties in finding the first job. At the same time, employers have problems in finding the suitable people.

Huge expectations are set on education in offering the demanded solutions. Especially higher education should be capable of assuring that their graduates have the necessary skills such as, e.g., be agile, have a solid understanding of how the workplaces work, be prepared see how their skills fit into to the changing environments of working life and for moving across jobs and sectors.

The situation becomes complicated through the substantial transformation taking place in education. It changes the position of higher education radically. Increasing number of students actively search for attractive learning opportunities and complete traditional formal instruction in various on- and off-line learning environments. A growing trend is also to complete the higher education diploma by chosen certificates which together gain substantial importance in the eyes of employers.
\end{abstract}

This paper presents the results of a study on the skills' requirement set by employers and the means of assessing them among the candidates in the recruitment. The results were analyzed using the qualitative content analysis with the "Entrepreneurship Competence Framework" as a theoretical background. According to the results, much emphasis is set on entrepreneurship although only occasionally any measures are taken to confirm their presence or absence among candidates through the recruitment process.

The paper discusses various approaches to solving the skill-mismatch. Digitalization which modifies working life can genuinely bring also the best solutions for solving the problem.

Keywords: skills mismatch, higher education, entrepreneurship, stakeholders, roles, tasks.

\section{INTRODUCTION}

\subsection{The Skills Mismatch}

Youth unemployment has become a severe problem in both industrialized and developing countries. The increase in unemployment has been more significant for young people $(18.7 \%$ in 2016 against $15.7 \%$ in 2007$)$ than for prime-age $(8.2 \%$ against $6.4 \%)$ and older workers $(6.5 \%$ against $5.4 \%)$. Moreover, long-term unemployment is more frequent in Europe among people aged 15-24 years $(5,5 \%)$ than that recorded for prime-age and older workers $(3.9 \%$ for both). It means that almost onethird $(29.5 \%)$ of unemployed young people are long-term unemployed. In 2016, nearly 1.3 million young people in the EU were out of work and actively seeking employment for at least 12 months. In this regard, Denmark, Finland, and Sweden all recorded long-term unemployment rates below $10 \%$ while, at the other end of the spectrum, Greece and Italy recorded rates above $50 \%$. Conversely, Ireland, as well as eastern European countries such as Bulgaria, Romania, Slovakia and Slovenia recorded much higher long-term youth unemployment rates than would be expected given their levels of youth unemployment [1].

Lack of education and lack of work experience are the two main driving factors in increasing the likelihood of a young person becoming long-term unemployed (Eurofound, 2017). Even young European graduates are now obliged to submit tens of (in the average 60) applications for their first job. One out of two European graduates are worried about their career, and with time some give up hope of getting employed in their field [2].

Despite the growing number of people seeking jobs in Europe, some sectors and employers are simultaneously reporting shortages of specific skills. In the European company survey (2013), around $38 \%$ of the EU companies said that they could not find candidates with the right skills [3]. 
Groeneveld \& Hartog (2004) reported that "education and training of the workforce should match occupational requirements, and the extent to which this process is successful is a major factor shaping labor market outcomes, productivity and economic growth" [4]. The economic crisis and identified skills mismatch have been considered as a major constraint hampering economic recovery in Europe. According to the recent ILO report, the "skills mismatch continues to be a topic of strong interest as it is an important factor affecting labor market and economic outcomes." This skills mismatch refers mostly to "overeducation and undereducation" [5].

The so-called "educational mismatch" is defined as the gap between the competences "formally required to obtain the job rather than the one considered by the employee to be the most appropriate to carry out the job tasks." The educational mismatch can be due to the employers' lack of understanding of the skills associated with various lines and levels of education [6]. The fields of education have developed rapidly. Many employers can lack possibilities of keeping up with the field of education even in their hometown institutes.

The skills mismatch can also be defined as the difference between the competence requirements of the employer and the competences presented by the job seeker. The applicants can lack information on the exact requirements of the job leading to lack of mutual understanding and reduced correspondence between formal" requirements and employee perceptions [6]. This gap here called as "the job seeker related mismatch" is due to the misunderstanding of the requirement among job seekers, who do not always recognize the employee requirements and priorities set by the business and are not prepared to present them in recruitment situations appropriately. Young graduates may concentrate too much on, e.g., diplomas, theoretical knowledge, and technical skills whereas recruiters look increasingly for transversal competences such as agility, flexibility, creativity, critical thinking, and problem-solving which traditional certificates do not give much information.

\subsection{Acquiring Skills and Competences}

Jobs and their content evolve with such a space that anticipation of future skill and competence requirements remains extremely challenging even though much effort is put into predicting them. In recent years, meta-cognitive, soft, transversal or entrepreneurial skills, have been in the center of discussion among researchers, education institutes, authorities and decision makers. In 2006 the European Commission (ANC 2006/962/EC) defined the eight Key Competences, necessary for all members of a knowledge-based society.

Competences are not innate, inborn characteristics but learned characteristics. They can be acquired within an educational or a social context and then transferred to a career, and generally, be used and developed in all areas of people's life. Learning competences is an ongoing, lifelong, learning process which occurs in multiple settings. The settings and social institutions relevant to the development of competencies besides school are relatives, peers, work, political life, religious life, cultural life, etc. Competency learning is not only a matter of personal effort. The development of competences assumes a favorable social and ecological environment, which includes but goes beyond the satisfaction of basic needs (food, housing, health, etc.). It is also dependent on the quantity and quality of learning opportunities. Therefore, the structure of the economy and social institutions plays a significant role in the development of competencies." [7] [8]

Changes in working life and societies oblige to reconsider the qualifications, knowledge, skills, and competences, necessary in professional and personal life. Entrepreneurship applies to all spheres of life and facilitates citizens' personal development, to active contribution to social development, entrance the job market, self-employment, or to start-up ventures of cultural, social or commercial motive. Entrepreneurship covers according to this definition more than just competences required for employability. [9]

Entrepreneurship is considered to consist of 15 competences the importance of which varies in different situations and environments. These are divided into three groups:

1 Into action (taking the initiative, planning \& management, coping with ambiguity, uncertainty \& risk, working with others, learning from experience);

2 Resources (self-awareness \& self-efficacy, motivation \& perseverance, mobilizing resources, financial \& economic literacy, mobilizing others);

3 Ideas and opportunities (spotting opportunities, creativity, vision, valuing ideas, ethical \& sustainable thinking). [9] 
Recent studies have shown that people with so-called "growth mind-set," who believe that they can develop their competences, (vs. fixed mind-set) work and learn more effectively and display a desire for challenge and resilience in the face of failure. Whereas, people with a 'fixed mind-set' believe that "you either are smart, or you are not" and therefore they are not interested in developing themselves and are unwilling to tackle new challenges. Studies show that when students undertake an intervention to move them from a "fixed" to a "growth mind-set" they immediately start performing at higher levels [10].

To achieve the change, young people should first be able to identify their intrinsic vocation, own mission, vision, potential or ambition. This has been described by the metaphoric definition of selfmobility: "One thinks own thoughts and goes own way." Self-mobility refers to the Slovenian term "samomobilnost" which was invented in 2004 within institute Center Spirala [11] as a neologism and then developed into a concept in 2007 by previous findings.

\subsection{Promoting and Facilitating Learning}

Numerous papers claim that education should bring the appropriate solutions. Especially higher education (HE) should apply changes that assure graduates with a solid understanding of how the workplaces work.

Students should be prepared to see how their skills fit into to the changing environments of working life and for moving across jobs and sectors. This challenges education and requires new ways of teaching and learning approaches such as:

- transition from teacher to learner centred approach;

- shift of responsibility for learning to the learner;

- offer team-working opportunities aside to individual work;

- replace pure memorizing by learning to find, critically evaluate, select and apply information;

- evolution from theory centred approach towards educational environments and methods where learning happens "in, through and for" authentic working-life challenges;

- transition from monodisciplinary to multidisciplinary, interdisciplinary or transdisciplinary learning environments;

- integration of digital communication for promotion of collaboration and participation and avoidance of exclusion;

- inclusion of learning self- and peer-assessment as an essential part of the curricula. [12] [13]

Business world and universities are challenged to share the responsibility and creating awareness on both sides of the complexities of the other. The European Centre for the Development of Vocational Training (Cedefop) skill mismatch research and European skills and jobs (ESJ) survey 2013 show that European Union (EU) countries with more responsive education and training systems are likely to experience fewer skill shortages and mismatches. [14] In a growing number of states, employers have a valuable role in education, though still limited in the Mediterranean and newer Member States [3].

The role of employers is also crucial, as better managed firms tend to have lower skill shortages" claims the Cedefop Expert Konstantinos Pouliakas. However, such difficulties do not necessarily arise because of skills deficits among job candidates. Hiring difficulties are often related to the offer of unattractive jobs or because some firms deploy inefficient recruitment and retention strategies. [14] Business should regularly identify their own needs and make them visible and understandable. Each partner should define their roles and tasks and assume them appropriately (Figure 1) [15].

The surrounding society can also participate in this action in various ways. As an example of this is the launch of the new "Decent Jobs for Youth" platform. The Global Initiative on Decent Jobs for Youth, launched in 2016 with the endorsement of the executive heads of the United Nations "has evolved as the overarching and inclusive platform under the 2030 Agenda for Sustainable Development to scale up action and impact on youth employment". The partners launched in November 2017 jointly a new engagement platform (www.decentjobsforyouth.org) for creating real change for young people across the globe. The ILO Toolkit for Quality Apprenticeships which provides state of the art information and guidance for the design and implementation of quality apprenticeship schemes across different contexts is available on the platform. 


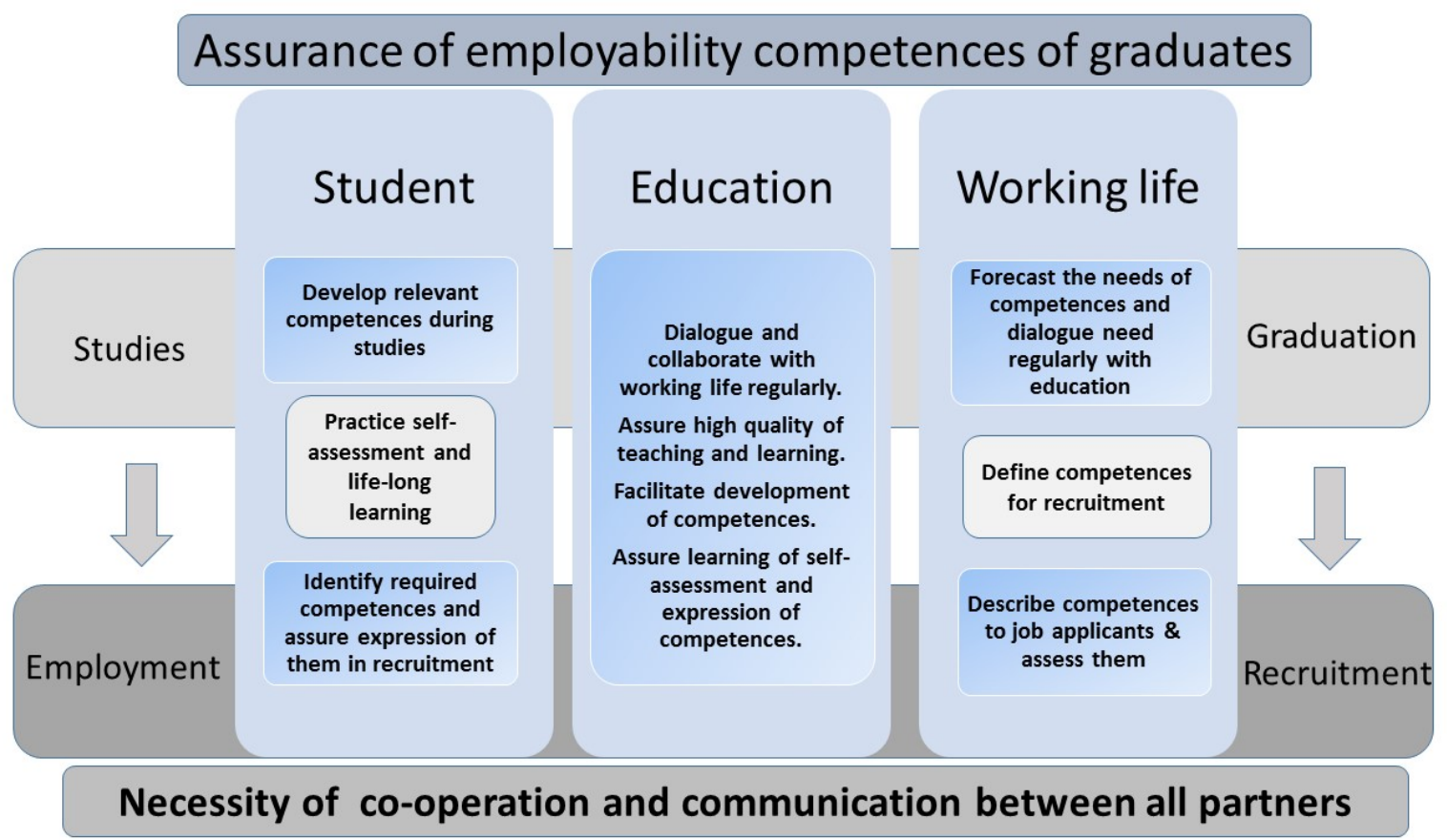

Figure 1. Development of employability through co-operation and communication [15]

\subsection{Aim of the study}

Several research and development actions have been taken to solve the problem of the skills mismatch. The goal of this study was to help graduating business students to prepare well themselves for recruitment and develop their employability. The aim was to identify the employability skills and priorities given by employers.

The research questions were:

1 What are the employability competences?

2 Do young graduates express them?

3 How will the requirements change in the future?

\section{METHODOLOGY}

\subsection{Methods}

Information on the employability competences was collected by semi-structured interviews of employers.

According to literature, semi-structured interviews are commonly used and flexible for gathering information on a particular topic. The interview situation is then designed, the interviewer becomes familiar with the subject and guides the interview. Initially, the interviewer describes the study process and how the interview proceeds [16]. The form of questions may be the same for all interviewees, but the order may vary, or the wording of the questions may be modified if necessary during the interview. Respondents answer the questions freely without the ready answers [17].

The interviewer's success can be affected by the lack of experience of the interviewer in using the method involving many practical challenges, such as agreeing to interviews, interviewing and disassembling recorded interview material [18].

The "Entrepreuneurship Competence Framework" [9] was used as a basis for the study and as a link between business and education. The concept was considered to apply to various situations and serve as a flexible source of inspiration for the interviewees. 
Interviews were conducted face-to-face as this increases both understanding, tone, speech and nonverbal communication and can be interpreted to enhance credibility or suspicion. The duration of one interview was approximately 30 minutes. The language of the discussions was English or Finnish.

The themes were the following: a) the five (5) most essential employability competences; b) frequency among job seekers; c) means of detection in recruitment situations; d) les important competences; e) future requirements.

Laurea Campus at Hyvinkää in Southern Finland was responsible for the realization of the field work. Six students in Degree Programme in Business Administration (BBA) were in charge of interviews. Their Peer to Peer (P2P) learning environment, is a way of studying by integrating learning in real business projects. Students work in teams on the client company's assignment. Theory is learnt of studying books and academic papers selected in accordance with the teachers. Learning is expressed in the project and related reports.

The interviews were mainly realised by student-pairs: one student concentrated on the interviewee, and the other one was in charge of audio-video recording the session.

The students familiarized with the subject from the theoretical and practical point of view and the interview themes were debated together. They had previously learned research methods but had here also the occasion of learning more about interview techniques. On this basis, the students made written plans for each interview and recording.

\subsection{Material}

For defining the interviewees, the students collected information on the eventual job environments available for a graduate in the Bachelor of Business Administration in Southern Finland. The aim was to cover as many sectors as possible including finance, real-estate, game development industry, human resources, online-marketing, and entrepreneurship.

The study covered thirteen companies from the following lines of business: marketing, well-being, public administration, game industry, metal industry, financing, HR, e-commerce and entrepreneurship (real estate business and traveling). Companies such as Opset (banking), Piha- ja puistosuunnittelu (environment design), IImarinen (insurances), Careone, City of Helsinki, Kone (Logistics), Fingersoft (software design) and Adtraction (marketing).took part in the interviews.

The interviews were realized in autumn 2017. Five out of the 13 interviews were filmed. The eight other interviews were held by phone or by email. Also, one interview was conducted at the respondent's workplace, and it was recorded on tape. All recordings were stored on USB-sticks for analysis. Interview videos were later edited, and English translations were added to those which were initially in the Finnish language.

\subsection{Analysis of results}

The project team edited the videos and transcribed the interviews. The original expressions were documented and then placed under a competence-chart created on the basis of the Entrepreneurship Competence Framework. The analysis was done by using the content analysis methodology: "Content analysis entails a systematic reading of a body of texts, images, and symbolic matter, not necessary from an author's or user's perspective"..."Through classification, tabulation, and evaluation of its key symbols and themes" meanings and probable effects are drawn from the analyzed data [19]. The incidence of the essential competences among job applicants was recorded according to the frequency of their appearance among the data (standard - quite common - rare - very rare).

\section{RESULTS}

Social skills and working with others were the most essential competences. Self-management and language skills were also considered critical by some respondents but not by everyone. Companies that do not practice foreign language on daily basis, considered language skills less valuable than others. The ability to cope with change and IT-skills were also among the often cited requirements. Figure 2 shows the most important common working life competences in BBA's line of work. 


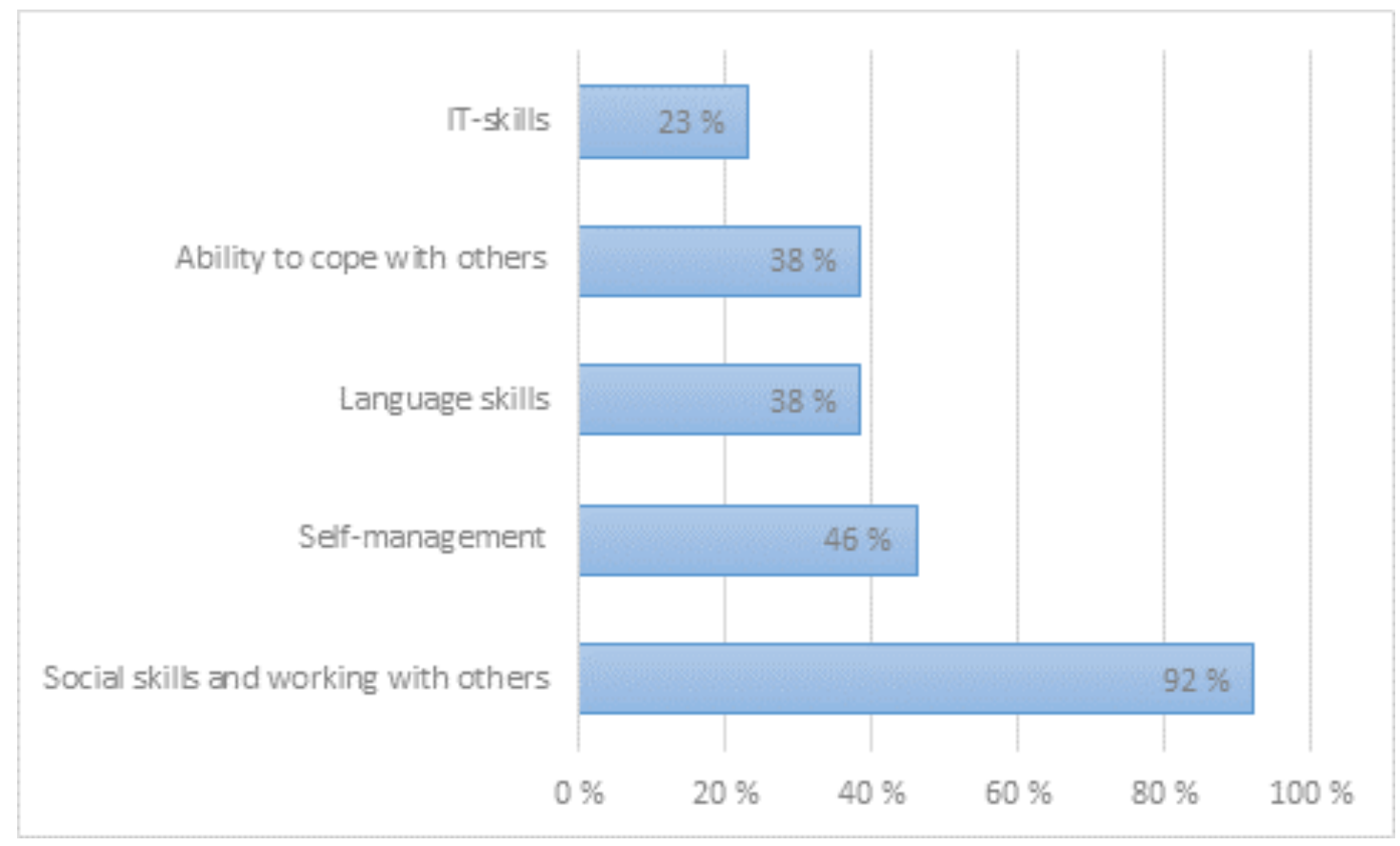

Figure 2: The essential competences required from BBA graduates in Finland $(N=13, n=31)$

The results among respondents were a bit more unanimous when the question of non-essential competences came up. Jurisprudence was the clearly the most often cited "not so important" one. Other non-essential competences that were mentioned by the respondents were more detailed to a specific field. These answers included physical strength, accounting, and cultural knowledge, as these can be important in some fields but not in others.

The respondents stated that the variable that would shape the needed competences in the future could be digitalization, globalization, changings in skill requirements and growing importance of networking. Special attention needs e.g., ability and willing-ness to utilize digitalisation, enthusiasm to learn and ability to cope with change, language skills and ability to work in a global environment, selfmanagement, understanding of data and analytics and interaction skills.

The interviewees considered very difficult to answer the question concerning the assessment of competences in a job-interview situation. Many respondents were confident that no non-essential skill are brought up in such cases as the job-advert usually lists the required competences. The experience was considered as the main way to learn the needed competences, and in this way, the amount of exposure was considered as the best measure to be used in comparing candidates.

\section{CONCLUSIONS}

Previous research supports the results this study. In many answers there were mentioned the fast changes of work, roles and skills needed. The future was considered fast changing and work will often be of project or temporary nature. The ability and willingness to learn, and the readiness to face challenges and changes are more important than sporadic skills. Interaction and networking skills are highlighted when the work is done in changing teams and working environments. It will be important to be able to manage one's self and lead own work in the work and free time. It will also be important to improve own skills in free time. Changes in work life can be very fast and it will be good to be prepared for them.

Digital solutions, automatization, and robots will change work, and job requirements. However, many interviewees said that technology would not remove the importance of interaction between people. Digitalization will further bring various working environments closer and work will be done increasingly in international settings. These changes impose knowledge of different cultures and fluent language skills. Generally speaking, courage, curiosity and right attitude were considered more important than perfect knowledge of specific software or language.

The study revealed that the $\mathrm{P} 2 \mathrm{P}$ learning environment as it is realized in Laurea offers students proper readiness for work. Students can learn the crucial working life competences that the respondents 
mentioned, as they are studying for a degree. Learning takes place in real business projects in collaboration with the companies. P2P-students get to develop their interaction, networking, presentation, language and IT- skills during their studies. The P2P-studying requires good selfmanagement and time control from the student.

To summarize, learners have to apply a clear role in learning as well as in evaluating their learning outcomes. This is important considering the substantial transformation taking place in education. Increasing number of students actively search for attractive learning opportunities and complete traditional formal instruction in various on- and off-line learning environments. A growing trend is also to complete the higher education diploma by chosen certificates which together gain substantial importance in the eyes of employers.

The study gives reason to think that suitable assessment methods of competences should be developed for use in recruitment interviews. These should be easily adaptable to various fields of business and usable by different categories of recruiters.

\section{ACKNOWLEDGEMENTS}

This study was supported by the European Commission, Erasmus Plus program - Cooperation for innovation and the exchange of good practices, Strategic Partnerships for higher education, activity KA2, project no: 2016-1-IT02-KA203-024 and by Wihuri Foundation, Finland. This paper reflects the views only of the authors. Neither the European Commision nor Wihuri Foundation can be held responsible for any use which may be made of the information contained therein.

\section{REFERENCES}

[1] Eurofound. "Long-term unemployed youth: Characteristics and policy responses". Publications Office of the European Union, Luxembourg, 2017.

[2] Mourshed, M., Patel, J. \& Suder, K." Education to employment: Getting Europe's youth into work," 2014. Retrieved from: https://www.mckinsey.com/industries/social-sector/ourinsights/converting-education-to-employment-in-europe

[3] Cedefop. "Tackling unemployment while addressing skill mismatch: lessons from policy and practice in European Union countries". Luxembourg: Publications Office. Cedefop research paper; No 46. http://dx.doi.org/10.2801/648140, p.7, 2015.

[4] Groeneveld, S., \& Hartog, J. "Overeducation, wages and promotions within the firm". Labour Economics, 701-714, 2004.

[5] Sparreboom, T \& Tarvid, A. "Skills mismatch of natives and immigrants in Europe". International Labour Office, Conditions of Work and Equality Department, ILO. Switzerland: Geneva, 2017

[6] Di Pietro, G. \& Urwin, P.J. "Education and skills mismatch in the Italian graduate labour market". In: Royal Economic Society Annual Conference 2003, 07-09 Apr 2003, Warwick, UK, 2003..Retrieved from: http://westminsterresearch.wmin.ac.uk/id/eprint/666

[7] Rychen, D. S. \& Salganik, L. H. Definition and Selection of Key Competencies: Theoretical and Conceptual Foundations. INES GENERAL ASSEMBLY 2000. Retrieved from: http://www.deseco.admin.ch/bfs/deseco/en/index/02.parsys.69356.downloadList.26477.

[8] Sievers, A., Ranta, L. \& Guilland, A. "Creating Insight Among Students on Working Life Competences Through Problem Based Learning”. In L. Gómez Chova, A. López Martínez \& I. Candel Torres (eds.) ICERI2017 Conference Proceedings. 10th annual International Conference of Education, Research and Innovation, Spain: Seville, November, 2017. ISBN: 978-84-697-6957-7, ISSN: 2340-1095. Pages: 713-721. IATED Academy, Spain. doi: 10.21125/iceri.2017.0266, 2017.

[9] Bacigalupo, M., Kampylis, P., Punie, Y. \& Van den Brande, G. "EntreComp: The Entrepreneurship Competence Framework". Luxembourg: Publication Office of the European Union, 2016.

[10] Boaler, J. "Ability and Mathematics: the mindset revolution that is reshaping education". FORUM 55(1): 143-150, 2013. Retrieved from: http://www.you- cubed.org/wp content/uploads/14_Boaler_FORUM_55_1_web.pdf 
[11] Center Spirala. "Selfmobility-Research of the selfmobility level at group with university backgrounds", 2009. Retrieved from: Center Spirala, Slovenia, http://www.spirala.org/

[12] Guilland, A., Terzieva, L. \& Nieminen, S. Teaching and Learning transversal Competences in Higher Education. Learning from Erasmus+ Socces-Project. Proceedings of INTED2017 Conference, Spain:Valencia, March 2017, ISBN: 978-84-617-8491-2, pp. 1248-1254, 2017.

[13] Weimar, M. "Learner-Centered Teaching: Five Key Changes to Practice". 2nd ed. San Francisco: Jossey-Bass. ISBN: 9781118119280, 2013.

[14] Cedefop. "Shedding light on the Skill Mismatch in the European Labour Market. Interview of Cedefop expert Konstantinos Pouliakis". Skilset and Match, Cedefop Magazine for Promoting Learning for Work 10, 16-17, 2017.

[15] Ranta, L., Sievers, A. \& Guilland, A. "Shared Responsibility of Higher Education Institutes (HEI) and Their Partners in Assuring Nursing Students' Employability Skills". In L. Gómez Chova, A. López Martínez \& I. Candel Torres (eds.) ICERI2017 Conference Proceedings. 10th annual International Conference of Education, Research and Innovation, Spain:Sevilla, Novemer 2017. ISBN: 978-84-697-6957-7, ISSN: 2340-1095. pp: 1247-1255. IATED Academy, Spain. doi: 10.21125/iceri.2017.0412

[16] Patton, M. Q. Qualitative Research \& Evaluation Methods. 4th Edition. Thousand Oaks: Sage, 2015.

[17] Hirsjärvi S. \& Hurme H. Tutkimushaastattelu. Teemahaastattelun teoria ja käytäntö. Helsinki: University Press Gaudeamus, 2008.

[18] Tuomi, J. \& Sarajärvi, A. Laadullinen tutkimus ja sisällönanalyysi. 7. uudistettu painos. Helsinki:Tammi, 2011.

[19] Krippendorff, K. Content Analysis. An Introduction to Its Methodology 2nd Edition. USA: Sage Publications, 2004. 